\title{
EFL Teachers' Views on Learner Autonomy
}

\author{
Siti Nurfiqah \\ Universitas Pendidikan Indonesia \\ Bandung, Indonesia \\ yenilatipah@upi.edu
}

\begin{abstract}
Indonesia is one of the Asian countries which has just little field regarding learner autonomy. Moreover, it is still doubted that if teachers generally accept the views about learner autonomy or even to what extent they understand about it. As a response, this study was conducted to investigate the views of English foreign language teachers regarding learner autonomy and how these views promote learner autonomy. This research was a descriptive-analytical study approach. The form of the written interview was used in conducting the research and interpreted into the analysis of qualitative data. The participants in this study were five teachers who have been teaching for ten years. The findings showed that teachers' views of learner autonomy and the promotion of learner autonomy in this study were varied. The teachers' views of these areas of learner autonomy needed to be developed.
\end{abstract}

\section{Keywords: autonomy, belief, teacher's view}

\section{INTRODUCTION}

The concept of learner autonomy has been viewed as a major area of interest in teaching English as a Foreign Language (EFL) in Asia for many years. Since the last four decades, learner autonomy has been being considered an important aspect of the practice of language teaching. Lately, there are some research performed to investigate what autonomy is, how it is promoted, or learning styles, teaching and learning activities which have been researched and developed in countries such as Hong Kong (Benson, 2001; Littlewood, 2007) and Japan (Aoki, 2001) by Asian researchers. Nevertheless, their limit number has been done on the study of teachers' view of learner autonomy.

Indonesia is one of Asian country which has just little field regarding learner autonomy. It is still doubted that if teachers generally accept the views about learner autonomy or even to what extent they understand about it. Moreover, the curriculum in Indonesia is such a spoon-feeding which forces the teachers to teach many goals to be achieved in a short time. Facing this situation in developing teaching materials, it cannot be denied that teachers will give many assignments to students to achieve the aims of learning. Since the students have many subjects with many assignments and are demanded to achieve or to pass the standard score provided by the government, it seems to the researcher that it is not that easy having this situation for the students because it is impossible to finish their subjects by depending on such working with their friend and having teacher beside them. There are four characteristics of learner autonomy definition Holec (1981). First, autonomy is an ability to take charge of one's learning, which means learner autonomy a tool of the learner, not the process. Second, this attribute is not innate or in-born but necessarily is acquired through a systematic and purposeful learning process. Third, it describes a potential capacity to act in a learning situation and not the actual behavior of an individual in that situation. Based on Holec's definition, learner autonomy cannot be separated as one single behavior in a particular learning context. The fourth characteristic relates to learners' ability to have control of their learning, to be responsible for the decisions-making in the learning process but do not necessarily undertaking the implementation of those decisions' (Dickinson, 1987).

Based on this concept, being learner autonomy is the best way for the students to solve their problems. Learner autonomy is the capacity of the learner to make decisions and take charge of their learning Little (1991). This kind of learning provides adults with life-long learning opportunities (Holec, 1981), which can be helpful for human learning in a long period.

Teachers' beliefs are formed based on teachers' schooling experiences as students when they used to observed teachers who taught them. Beliefs depend on teachers' experience and are true for the person who holds them (Díaz, Martínez, Roa \& Sanhueza, 2010). Regarding this statement, the way teachers see the process of teaching, developed from their experiences at school. Moreover, Teachers' beliefs of learner autonomy will transfer to the learners as they see and experience what they have in their school.

There are many ways how teachers' beliefs can be formed in their professional careers. Teachers have different beliefs on issues in education and they have an important influence on their teaching (Pajares, 1992). In this regard, a teacher is a person who brings a relationship in teaching-learning and helps the students to have a supportive learning environment that allows learners to develop in their way. On the other hand, the information on teachers' beliefs is still blurry for teachers. The second factor in which teachers' level of their own beliefs reflects their instructional practices. Furthermore, these two factors shape and influence teachers' thinking and their relationship to practice including awareness of having adopted specific views and assumptions of the subject matter or issue; the ability to justify these views and assumptions (Ernest, 1989). These two factors can give opportunities that impact teachers' beliefs and their actual teaching of autonomy.

How teachers implement learner autonomy in the classroom needs to bring the correct point of view of autonomy into the practice to build professionalism, because how teachers' beliefs about what autonomy is, its desirability and feasibility, will also influence. Palfreyman (2003) found that there is still the gap 
that maybe happened between theoretical discussions of learner autonomy and teachers' perceptions of the concept and the point with specific reference regarding the manner of learner autonomy which was conceptualized from technical, psychological, and political perspectives (Benson, 1997) and, from a sociocultural perspective (Oxford, 2003).

An important point about learner autonomy is it allows and encourages choice and decision-making at different levels of education to the development of student autonomy in both studies in the classroom and study outside the classroom. However, the choices and decisions made by learners have to be both informed and meaningful to the students themselves (Benson, 2003), which focuses on the personal relevance of learning and ownership of the language learner, the important issues of autonomy in language learning. Having the right choice and decision will allow the students to have desirable learning.

\section{METHOD}

This research was a descriptive-analytical study approach as its design. This kind of study set out to describe and interpret the thing and what event has influenced and affected a present condition (Cohen, Manion, \& Morrison, 2007). In this research, the researcher interpreted the data analysis of qualitative data. A survey in the form of the written interviews was used in conducting the research.

The respondents in this study were 5 teachers. The research instrument was in the form of a written interview.

\section{FINDINGS AND DISCUSSION}

This section reports on the results which aim to explore teachers' beliefs about learner autonomy. The findings and discussion as follow:

\section{A. Participant 1}

\section{Autonomy Mean to Participant 1}

According to participant 1, autonomy is a part of selfdetermination theory where the students are free to have a choice in the style of learning. When asked about the characteristic of learner autonomy, participant 1 answered that the characteristic of autonomy learner is a choice in learning. Participant 1 stated that the relationship between learner autonomy and language learning is the autonomous learner has built self-regulation.

When asked about the issue of learner autonomy, participant 1 said: "Autonomy learner is as an issue in language teacher environment indeed, it has been theoretically considered as an important issue to develop learners". Participant 1 added that learner autonomy was just an issue in theoretically, not in practically He found in working, in the context where autonomy has been considered an important thing to be developed. When asked about His awareness about this issue, as a language learner, participant 1 never being aware of that autonomy has been being an issue just when He had taken His master's degree.

Participant 1's view on the practices promoting learner autonomy

In promoting learner autonomy, participant 1 said that there was a change of teacher' behavior in the classroom such as roles as a motivator who encourages and gives them the choice of what they want to work on. Participant 1 has done practices in the classroom to promote autonomy, He described, "at some level, it seems to me that students are more enjoy and feel relaxed having these practices". He also added additional practice in teaching that $\mathrm{He}$ also tried to focus on students' voices and choices.

The data above indicated that participant 1 had unclear information about the meaning of autonomy learner. Even though $\mathrm{He}$ just theoretically being in the context where autonomy has been considered an important issue, $\mathrm{He}$ expressed the belief that students can choose what style they want for learning freely with the teacher who is as a motivator to support students doing their chosen style of learning. However, being autonomous is not just about the choice of having learned, there are other aspects should be considered its account. Moreover, the awareness of participant 1 is not high regarding the issue of autonomy happened because He just knew this issue while undertaking a master's degree program. It indicated that He never heard this term and participant 1 try to foster students being autonomous.

\section{B. Participant 2}

\section{Autonomy Mean to Participant}

Regarding the meaning of autonomy, participant 2 stated that "now, students can learn by themselves in and outside the classroom". He added the characteristic of learner autonomy was having a strategy to and could employ learning strategy for the students. He also described that language learning should not be confined in a classroom. According to him, students who have autonomy in learning can improve themselves outside the classroom. He felt that learner autonomy was being an issue $\mathrm{He}$ had focused on His training as a language teacher where $\mathrm{He}$ is being a teacher trainer and speaker in the workshop.

\section{Participant 2 's view on the practices promoting learner} autonomy

In promoting autonomy, participant 2 indicated that teacher roles as the facilitator who encourages the students by giving the facilitation and the control of learning as much as possible. Moreover, He added that the school operates can also change by supporting more e-learning through the e-learning platform. He has had all practices provided in the interview,

"I have done all the practices put here, I choose 1 to 20"

Supporting those practices, He has been using materials and computers, stronger the students to help him in teaching. "I have been trying to avoid spoon-feeding the students as much as possible". He also put an extreme way of teaching:

"I did once was using "The Silent Way" in a class that depended on for everything; so they had to rely on themselves and each other to answer a question they had a class".

From the data of participant 2 , it indicated that He viewed learner autonomy by the strategy which allowed the students to lean everywhere they want. He focused on the strategy to learn and to employ learning for students. It indicated that His view regarding autonomy learner is still weak because $\mathrm{He}$ just focused on one aspect. Regarding autonomy as an issue in the language teaching process, He aware of the context in which he is a teacher trainer and speaker in the workshop. Based on what 
He has done in His work, it is clearly stated that He takes the issue of autonomy into account.

In promoting learner autonomy, participant 2 stated that the teacher is a facilitator and controller. It indicates that He knew that fostering learner autonomy to the students does not mean that the teacher just let the students do learning without a teacher. His opinion also supported by what He has done in the teaching process. He has used all of the practices given. Moreover, $\mathrm{He}$ also has additional materials and computers to enhance the students' understanding of learning. Regarding the case, once, He tried using "The Silent Way" in the class, asking the students to be independent doing tasks. This indicated that He pays attention to make students autonomous.

\section{Participant 3}

\section{Autonomy Mean to Participant 3}

According to participant 3, learner autonomy is the student who being active and standing alone without being forced by others. The students are motivated to study by themselves. Moreover, the students have their knowledge which can help themselves in the learning process. I have been developing learner autonomy, but it seems to me that the students are lazy in all subjects at school. I never find any issue regarding learner autonomy in my training as a language teacher. In my experience, I also was not aware of learner autonomy has been considered an important issue to develop with learners.

Participant 3 's view on the practices promoting learner autonomy

In the teaching process, $\mathrm{He}$, as a controller, tried to give the students a lot of motivation to encourage autonomy to the learners by having rules in the teaching and learning process. Regarding this, His teaching place never supports him, the teachers, to promote learner autonomy. However, in promoting learner autonomy in His practice, He has been using almost all practices provided by the researcher, except number $5,13,17$, and 18 (shown in the appendix). By having those practices, the students do not feel bored.

Based on the data, participant 3 viewed learner autonomy as freedom of human rights without any force from others, the students learn because they want to. He believes that the students have their ways which helps them develop their study. Furthermore, the data showed that participant 3 has tried developing learner autonomy as the controller, but the condition of the students did not support him. Having this problem, he /she did not put this matter into account as an issue of learner autonomy, because $\mathrm{He}$ did not aware much that it should be considered as an important issue in developing learner autonomy. It indicated that He did not put any influence on the students whether by implementing the practice or motivation which makes students feel encouraged to learn autonomously.

On the other hand, the data showed that He had already been using most of the practices in the list for teaching with the condition in which He did not have any concept before that the practices they had are actually to foster learner autonomy to students. In this part, it can be indicated that He had slightly belief of learner autonomy and His view did not work in applying the practices regarding promoting learner autonomy in teaching.

\section{Participant 4}

\section{Autonomy Mean to Participant 4}

According to participant 4, in learner autonomy, the learners have their insight into their learning styles and strategies or independent learners. He mentioned that this kind of learning would help students develop gradually from teacher dependence to the student center. In the language learning process, He added that learner autonomy was very important because the students should be active and creative. According to him:

"learner autonomy has been considered as an important issue to develop with the learner and I aware of this problem". However, He said, "in my working place, I never find that learner autonomy considered the important issue".

In promoting autonomy learner, participant 4 did not want to have teacher central, He gave more opportunities for students to be active. In encouraging autonomy, He tried to support the students through reading, listening to songs, poems, having a role, etc. Sometimes, the school also allows him to bring the students conducting the learning process out of class, such as in the school park and lab. In promoting autonomy learners, participant 4 has done most of the practices except number 6 (shown in the appendix). Those practices are more effective to encourage the learners to be autonomous. In addition regarding promoting learner autonomy, "I ever asked my students to find a native speaker to practice their conversation skill, but the result showed that it was very hard for the students, only a few of them could do that", He said.

The data above indicated that participant 4 viewed autonomy learners as the students' idea of how to learn by themselves actively and creatively. It can be seen in the data that He was strongly aware learner autonomy is considered an important issue in teaching, However, participant 4 thought that He found nothing in His workplace where learner autonomy was being an important matter in developing students' learning. Furthermore, the data indicated that even participant 4 did not find that learner autonomy is considered an important point in His workplace.

In promoting learner autonomy, $\mathrm{He}$, supported by the school, still has a strong effort in promoting this matter to students, such as having done practices in the list and having a special way of encouraging students' independent learning.

\section{E. Participant 5}

Autonomy Mean to Participant 5

According to participant 5, learner autonomy viewed as a condition in which students always motivated to learn with or without a teacher so that they can understand their goal of learning. He also mentioned that learner autonomy would support students in achieving their goal of learning a language as a tool of communication. In His working place, learner autonomy has been considered an important issue to develop with learners; it still in term of school implicit program, and "I am being aware of this", He said.

Participant 5 's view on the practices promoting learner autonomy 
Participant 5 stated that the teacher is as a motivator and tutor in promoting learner autonomy. To encourage the students to be autonomous, participant 5 gave the students a problem and asked them to solve the problem given. In participant 5 working place, there is no change and support from school about promoting learner autonomy, because this issue is still new in my place. There are some practices $\mathrm{He}$ has been using in promoting autonomy learners such as numbers $1,3,4,9,10,15$, 17, and 19 (shown in the appendix). He uses these practices to provoke the students to always try to learn by themselves. Furthermore, participant 5 ever asked my student to be a problem solver regarding the problem which I set before. It can be seen that participant 5 seen autonomy learner is a kind of independent learning style of students to achieve what they want to achieve with the teacher as a motivator and tutor. From the data, He was aware of learner autonomy is considered an important issue. Moreover, participant 5 has already done some practices on the list to provoke developing students by trying to learn autonomously. Regarding this, He also has a special way to make students in developing their learner autonomy. It indicated that He did pay attention to encourage the students to be autonomous.

\section{CONCLUSION}

As presented above, the researcher concludes that the teachers' view in this study held a wide range of beliefs about learner autonomy. They viewed learner autonomy as learning choice, strategy, and style in learning and independent learning. Teachers also characterized learner autonomy with a variety of answers such as choice, study place, motivation, student center, and goal. It also found blurry for some participants' views indicating the teachers' roles in promoting autonomy learners. They have various beliefs about learner autonomy including misconceptions among autonomy which they think as independent learning without any clear roles of teachers to support their students' activities.

\section{REFERENCES}

Aoki, N. (2001). The institutional and psychological contexts of learner autonomy. In L. Dam (Ed.), Learner autonomy: New insights (pp. 72-90) Milton Keynes: AILA Review.

Benson, P. (1997). The philosophy and politics of learner autonomy. In P. Benson \& P. Voller (Eds.), Autonomy and independence in language learning (pp. 18-34). New York: Longman.

Benson, P. (2001). Teaching and researching autonomy in language learning. London: Longman.

Benson, P. (2003). Learner autonomy in the classroom. Practical English Language Teaching, 1, 289-308.

Cohen, L. Manion, L., \& Morrison, K. (2007). Research method in education $\left(6^{\text {th }}\right.$ ed $)$. New York: Routledge.

Díaz, C., Martínez, P., Roa, I., \& Sanhueza, M. (2010). Una fotografía de las cogniciones de un grupo de docentes de inglés de secundaria acerca de la enseñanza y aprendizaje del idioma en establecimientos educacionales públicos de Chile. Folios, 31, 69-80.

Dickinson, L. (1987). Self-instruction in language learning. Cambridge: Cambridge University Press.

Ennis, C. D. (1994). Knowledge and beliefs underlying curricular expertise. Quest, 46, 164-175.

Ernest, P. (1989). The impacts of beliefs on the teaching of mathematics. In P. Ernest (Ed.), Mathematics teaching: The states of the art (pp. 249-254). London: Falmer Press.

Holec, H. (1981). Autonomy and foreign language learning. Oxford: Pergamon Press.

Littlewood, W. (2007). Communicative and task-based in language teaching in East Asian classrooms. Language Teaching, 40(1), 243-249. DOI: $10.1017 / \mathrm{S} 0261444807004363$

Little, D. (1991). Learner autonomy 1: Definitions, issues, and problems. Dublin: Authentik.

Loi, N. V. (2016). Learner autonomy in Vietnam: Insights from English language teachers' beliefs and practice. Phnom Penh: IDP Education.

Mansour, N. (2013). Consistencies and inconsistencies between science teachers' beliefs and practices. International Journal of Science Education, 35(7), 1230-1275.

Oxford, R. L. (2003). Toward a more systematic model of L2 learner autonomy. In D. Palfreyman \& R. C. Smith (Eds.), Learner autonomy acros cultures: Language education perspectives (pp. 75-91). Bangsingstoke: Palgrave Macmillan.

Pajares, M. F. (1992). Teachers' beliefs and educational research: Cleaning up a messy construct. Review of Educational Research, 62(3), 307-332.

Palfreyman, D. (2003). Introduction: Culture and learner autonomy. In D. Palfreyman \& R. C. Smith (Eds.), Learner autonomy across cultures language education perspectives (pp. 1-7). Bangsingstoke: Palgrave Macmillan. 